EIGHTEENTH-CENTURY WRITERS IN THEIR WORLD 


\section{Eighteenth-Century Writers in their World}

A Mighty Maze

Andrew Varney 
First published in Great Britain 1999 by

MACMILLAN PRESS LTD

Houndmills, Basingstoke, Hampshire RG21 6XS and London

Companies and representatives throughout the world

A catalogue record for this book is available from the British Library.

ISBN 978-0-333-67973-9 ISBN 978-1-349-27763-6 (eBook)

DOI 10.1007/978-1-349-27763-6

First published in the United States of America 1999 by

ST. MARTIN'S PRESS, INC.,

Scholarly and Reference Division,

175 Fifth Avenue, New York, N.Y. 10010

ISBN 978-0-312-22531-5

Library of Congress Cataloging-in-Publication Data

Varney, Andrew.

Eighteenth-century writers in their world : a mighty maze / Andrew

Varney.

p. $\mathrm{cm}$.

Includes bibliographical references and index.

ISBN 978-0-312-22531-5 (cloth)

1. English literature-18th century-History and criticism.

2. Literature and society - Great Britain-History-18th century.

3. Literature and history-Great Britain-History-18th century.

I. Title.

IN PROCESS PR448.S64 V

$820.9^{\prime} 005-\mathrm{dc} 21$

99-22174

CIP

(C) Andrew Varney 1999

All rights reserved. No reproduction, copy or transmission of this publication may be made without written permission.

No paragraph of this publication may be reproduced, copied or transmitted save with written permission or in accordance with the provisions of the Copyright, Designs and Patents Act 1988, or under the terms of any licence permitting limited copying issued by the Copyright Licensing Agency, 90 Tottenham Court Road, London W1P 0LP.

Any person who does any unauthorised act in relation to this publication may be liable to criminal prosecution and civil claims for damages.

The author has asserted his right to be identified as the author of this work in accordance with the Copyright, Designs and Patents Act 1988.

This book is printed on paper suitable for recycling and made from fully managed and sustained forest sources.

$\begin{array}{llllllllll}10 & 9 & 8 & 7 & 6 & 5 & 4 & 3 & 2 & 1\end{array}$

$\begin{array}{llllllllll}08 & 07 & 06 & 05 & 04 & 03 & 02 & 01 & 00 & 99\end{array}$ 


\section{Contents}

Acknowledgements

$1 \quad$ Other Worlds - Narratives of Travel: Robinson Crusoe and Gulliver's Trapels

2 Wit and Virtue: The Way of the World and Clarissa

3 Money and Government:

Roxana and The Beggar's Opera

4 Men and Women - Love and Marriage:

The Rape of the Lock, Roderick Random and

Tom Jones

5 Writing by Women: the Female Poets and Mrs Manley 117 Appendix: Mrs Manley's Preface

6 The Harmony of Things:

An Essay on Man and Moral Essays

7 Science and Nature:

The Spectator, Gulliver's Travels and The Seasons

8 Country and City, the Choice of Life: Dr Johnson

Notes

Suggestions for Further Reading 


\section{Acknowledgements}

I hope this book shows some marks of how enjoyable it was to write. It was a rather diffuse project and in the course of completing it I have incurred debts promiscuously. I am profoundly grateful to all those whose names occur in the annotation, and to those whose names no doubt ought to appear there. I am always tremendously impressed by the way in which eighteenth-century writing elicits some of its own characteristics in those who study it, so that eighteenth-century scholarship takes on something of the flexibility, wit, mordancy, zest and humanity of its subject. I cannot aspire to match the diligence, knowledge or perceptiveness of those to whom I owe so much, but want to record anyway how exhilarating being in their debt can be.

I do, of course, owe more particular debts too, not least to Margaret Bartley at Macmillan for her enthusiastic support and tolerance as an editor. I am also extremely grateful to my friends and colleagues Mark Loveridge, a source of intriguing and original ideas over many years, and Ian Bell, who as Head of Department has given me continuous encouragement, and who as eighteenth-century scholar has been a source of valuable practical information and advice. I wish that I had designed into this book a chapter on friends and families: the eighteenth century in England was bracketed between periods which placed supreme importance on individual experience, but in the period itself the sense you get of the national life is of life and experience held in common, in some measure shared in a spirit of intimate acquaintance, amusement and tolerance. Had I written such a chapter it would have registered not only my sense of the period, but also my gratitude for the extraordinary kindness and supportiveness of my own friends and family while I have been writing this book. 


\section{Preface}

All works of literary recovery are to some degree a negotiation between the picayune and the grandiose, or between obsession and understanding. One chapter here spends rather a long time talking about pineapples; another outlines the impact of Newtonian science on the human imagination. This veering between Lilliputian detail and Brobdingnagian gesture reflects a conviction that the cultural world of early eighteenth-century Britain exhibited a kind of promiscuous interest in everything. The literary world was the real world, the world of common experience. Defoe made bricks and bred civet cats; Pope invested the money he received from translating Homer in the South Sea Company; Swift dined regularly with the prime minister and wrote political pamphlets; Thomson studied science; Addison bought a country estate so that he could become a member of parliament; Lady Mary Wortley Montagu was married to a diplomat, lived in Turkey and brought inoculation for smallpox to Britain. None of these facts receives particular attention here but the book is an attempt to record an awareness that writers of the period were citizens and that one way to approach their work is to understand something of the tidal flows which they were navigating.

Cultural recuperation is, however, barren without the cultural products - narratives, plays, poems - in which people represent themselves, construct a picture of their world and articulate their anxieties. Each chapter here attempts to describe a feature of the culture of early eighteenth-century Britain and to read some major works of the period in its context, but there were no rigid demarcations between topics and writers; culture is a conversation, not a discourse, and so there is inevitable repetition and overlapping. Some topics, the legal status (or non-status) of women for instance, and some passages of texts, such as Gulliver's observations on the relative scale of things, recur here in different discursive contexts. Culture is about recognition and repetition as well as about novelty and discovery, and it is accordingly proper to find an expression like Pope's 'Order in Variety' from Windsor-Forest at home in a discussion of landscape and of eighteenth-century political economy.

One conspicuous recurrence is reference to Thomson's The Seasons. 
This is not because a case is being made for his verse, which swerves between the sublime and the daft, but because his lifespan, 1700-48, coincides almost exactly with the cultural period this book covers, and because his poem is so compendious and so hospitable to many of the ideas and responses that filled the emotional and intellectual atmosphere of his times that he becomes in almost all fields a useful point of reference. His comparative ordinariness makes him useful in a way that a figure of scintillatingly idiosyncratic genius such as Swift cannot be. But an account of his times cannot be just an account of him; it has to take in the inventive vitality and distinctive energy of Defoe, Swift, Pope, Smollett and the others. Thomson's role here is a bit like that of Prufrock: '... not Prince Hamlet, nor . . . meant to be; . . . an attendant lord, one that will do / To swell a progress, start a scene or two ... Full of high sentence, but a bit obtuse; / At times, indeed, almost ridiculous - / Almost, at times, the Fool.' But it is none the less important in a culture with so many voices as the first half of the eighteenth century.

This book quotes those voices extensively, more perhaps than many academic works choose to do. This is partly because some of the material is unfamiliar - not many general readers, not all undergraduates or even all academics have Mandeville or Mrs Manley at their fingertips but more importantly because the period was a polyphony of articulations, a play of tones, witty, variable, intense, allusive, and they need to be seen and heard if the age is to come alive again at all. And some are irresistible and need no excuse. I have also quoted quite a lot from modern commentators, to all of whom I am profoundly in debt. The eighteenth century is not particularly buoyant in undergraduate literary studies at present, but cultural and scholarly investigation of the period is extremely vital and productive and, most importantly, pan-disciplinary. The eighteenth century is part of the discourse of our times; it is not locked away in the past. I have in the main not quoted much from studies of literary discourse or cultural theory, although certain assimilations and assumptions will be obvious. The voices I want to record are those of and about the culture of the first half of the eighteenth century.

Some of these voices are those of women, and there is now an increasing interest in and awareness of their significance. Apart from such writing as survives by women, the lives of women play a much bigger role in writing of this than of any earlier period: The Rape of the Lock, Moll Flanders, Clarissa - such major canonical works, though written by men, are about women and the conditions in which they had to negotiate their lives. The familial, literary, cultural and political power 
bases were of course dominated by men, but there is more and more recognition in the period that men shared the world with women and that women mattered. I have tried to register this here, but without falsifying the account.

Many of the works I discuss are familiar canonical texts of the first half of the eighteenth century - The Rape of the Lock, Robinson Crusoe, Gulliver's Travels and so forth. The aim is not to endorse the canon but to work with what is familiar, and of course with what undergraduate readers and other readers are commonly confronted with. Too often the texts are encountered as mighty islands in an unknown sea. One function of this book is to help chart that sea so that the texts begin to acquire meaning in terms of the cultural geography of their times and so to become more fully rewarding. This in its turn should facilitate access to the many-lesser known works which modern scholars are increasingly bringing into view and whose exploration is a source of enormous interest and entertainment.

Each chapter here can be read separately, but none offers a full account of its topic or of the texts for which that topic supplies a context. No full recovery of the period - of any period - or of the texts that animate it is possible, but the intention here is to offer an accumulation of contexts and texts that will help to fill some of the white paper on the map of the literate culture of the first half of the eighteenth century. 


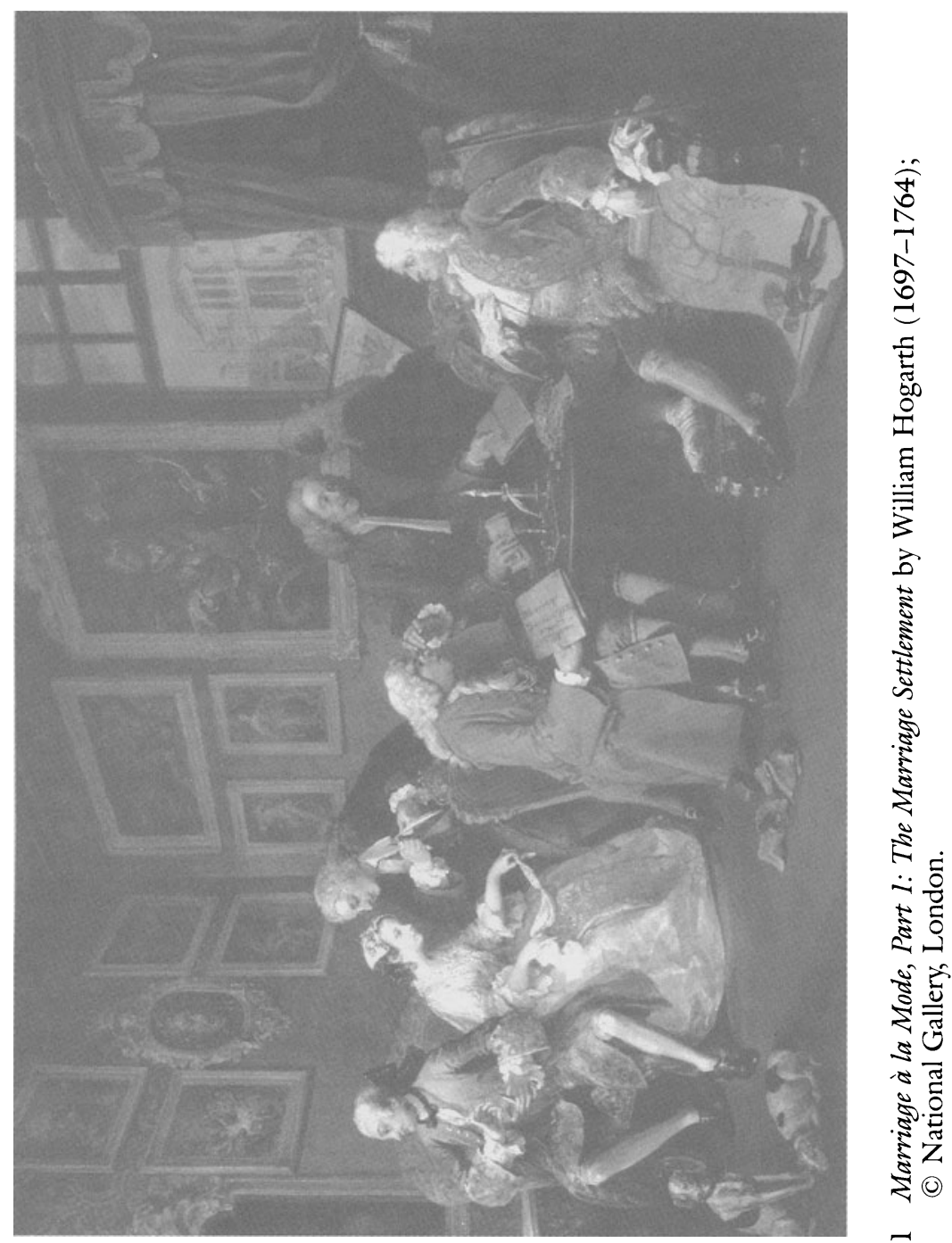




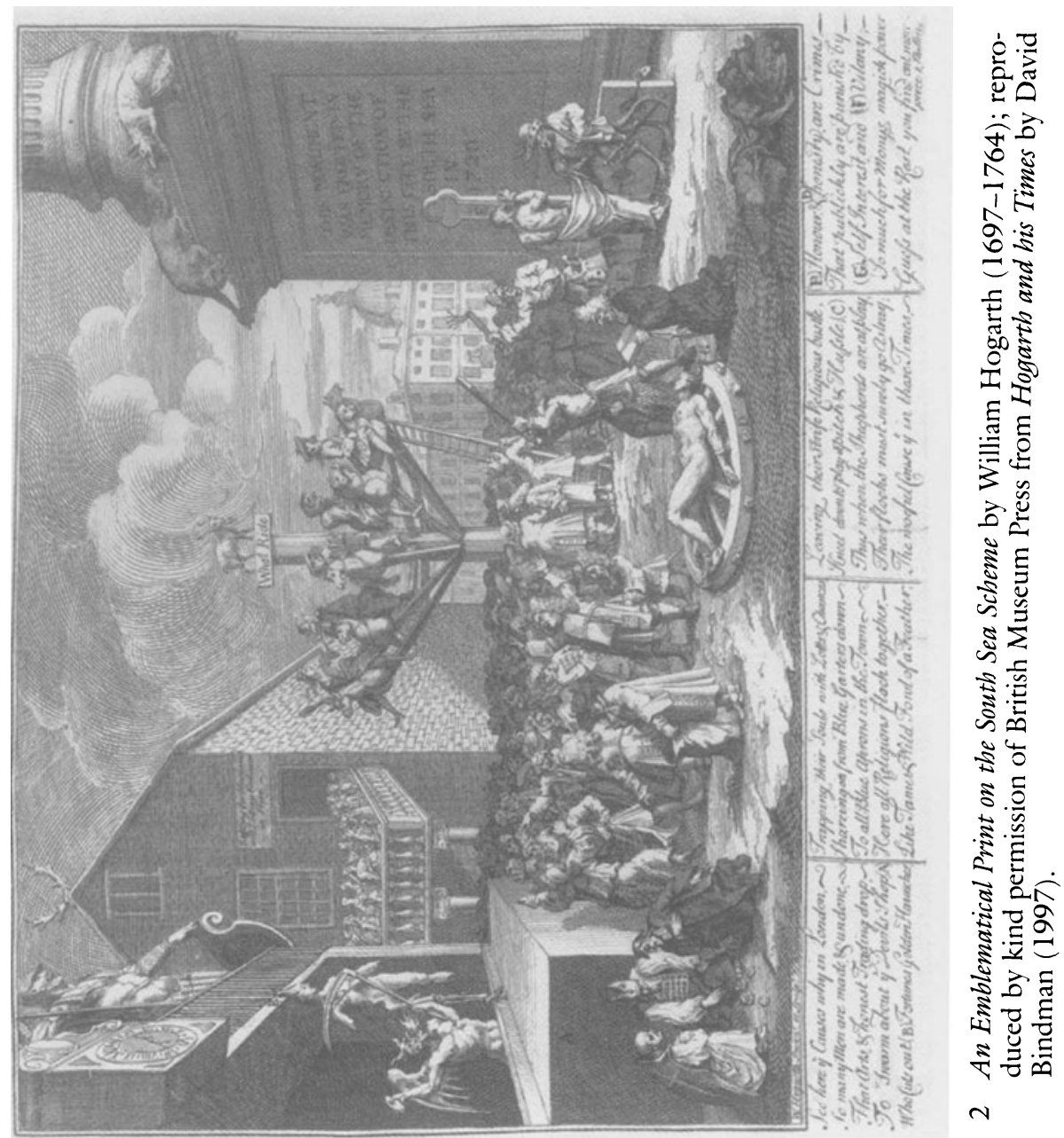

